\title{
Political Parties and Environmental Ethics: The Case of the Dutch Party for the Animals
}

\author{
Ruud Otten (Wageningen University, Rotten@aresco.nl) \\ Bart Gremmen (Wageningen University, bart.gremmen@wur.nl)
}

\section{Introduction}

In contemporary Europe, discussions about how we as humans relate to animals and how we should deal with them are often comprised of two completely different categories in which arguments and views can be grouped together (Gamborg et al. 2010). These two categories have their own distinct domain regarding the type of animals about which they are most concerned: domesticated animals and wild animals. Domesticated animals are comprised of pets, cattle, zoo animals and circus animals, whereas wild animals are those animals living autonomously in nature (i.e. outside the cultural, human domain). Both categories of animals have their own 'guardians', such as the animal protection agencies for domesticated animals and nature conservation organizations for wild animals.

This distinction between the two categories of animals with their associated rationalities is reflected in environmental philosophy in the form of two schools of thought (Klaver et al. 2002). Animal welfare ethics prioritizes the individual animal and, in doing so, refers to such values as 'intrinsic value', 'the integrity of the individual' and 'wellbeing'. Opposed to this line of thought is eco-ethics, which considers the wider interests of ecological entities (e.g. populations, species and ecosystems) as the ultimate greater good. Values such as 'biodiversity', 'naturalness' and the 'integrity of the ecosystem' are of prime importance here and are considered superior to the wellbeing of individual animals (Klaver et al. 2002; Gamborg et al. 2010). A precondition for this distinction is that the imaginary line between wild and domesticated animals is clear to everyone. In everyday practice however, it increasingly happens that there is actually a grey zone between the cultural domain of humans and their domesticated animals and the natural domain of self-regulating nature in which wild animals take care of themselves (see Rosenzweig 2003). This has led to a lot of controversy among the general public on issues that involve animals, and is one of the reasons for the establishment of a political animal party in the Netherlands.

The Partij voor de Dieren (Party for the Animals) was founded in 2002, and its raison d'être is to act as a representative for animals and their interests (Partij voor de Dieren 2011). According to the party, this initiative was a reaction to earlier administrations' policy and a wide array of measures considered by the party as animal unfriendly. It is rather unique because it is 
the only political party completely devoted to animals in the world. However, it may become an example for similar political parties in other countries in the future.

After some narrow defeats, 22 November 2006 was not only a historic day, as the party for the first time succeeded in getting a foothold (i.e. two seats) in the Dutch Parliament, but also the very first time that an animal party was elected to a national parliament (Partij voor de Dieren 2011). From that moment onwards, the party has continuously been strengthening its position and in the interim it has succeeded in having representatives on multiple governmental levels. Moreover, although animal welfare continues to be its main priority, the party's particular worldview provides it with a position on other, more 'typical' political issues as well (Partij voor de Dieren 2011).

The name of the party, Party for the Animals (literal translation of its Dutch equivalent, although we call it the Animal Party in the remainder of this article), suggests that the party should concern itself equally with all animals, thus including both domesticated and wild. This 'obligation' to focus on domestic as well as wild animals is also evident from the party's 2012 election program, which declares that the welfare of individual animals as well as broader ecological issues are among the party's major concerns. Because of this double focus, the Animal Party could be regarded as a possible 'solution' to the above-mentioned problematic animal issues. This formal party wants to take domestic as well as wild animals under its wing and, hence, to remove the traditional dividing line between both domains. However, there still remains the crucial question as to how the Animal Party will deal with different types of animals (i.e. with domestic, wild or semi-wild) in cases where the boundary between the natural and the cultural becomes blurred.

Regarding domestic animals, we expect the Animal Party to consistently emphasize the rights and wellbeing of the individual animal (i.e. in line with animal welfare ethics). Its attitude towards wild animals - e.g. when they are in trouble - will likely be more problematic (see: Swart 2005), as it also claims to value ecological concerns highly, and this can be at odds with some interventions. Another dilemma might occur in the case of the (re-)introduction of semi-wild animals into the wild, as there often seems to be a conflict about, for example, supplementary feeding and shooting, which might prevent animal suffering but may inhibit ecological processes. When the philosophical distinction between eco-ethics and animal welfare ethics is taken into account, it becomes clear that the party might occasionally face a serious dilemma when animal welfare and ecological values are found to be in conflict in a particular situation. As the Animal Party aspires to be a party for all animals, the question emerges as to how the party will deal with wild animals that are in trouble and with the animals that are a mix between wild and domesticated in the case of this problematic grey zone in between the cultural and the natural. In these kinds of situations, it is interesting to see whether the Animal Party will choose, in accordance with animal welfare ethics, the individual animal or, in line with 
eco-ethics, adopt a more passive, 'hands-off' approach. This question is the main topic of this paper.

First, we describe and analyse a fairly recent election program of the Animal Party to see how animal welfare and ecological concerns are linked to each other. Then, we look at the Animal Party's vision with regard to five potentially problematic issues. We use the following issue categories: 'hunting', 'exotic species', 'wild animals in trouble' (these three constitute the focus on wild animals), 'introduced semi-wild animals' (Janssen \& Drenthen 2013) and 'natural behaviour of domesticated animals'. After recounting the party's vision on these five issue categories, we describe and analyse the position of the Animal Party on specific issues within these categories, as outlined in its 2012 election program. Finally, we analyse specific situations within the five issue categories, which take place outside the 'paper reality' of the party's election program. Before we elaborate on these topics, a final thing that needs a little more consideration right away is the debate between eco-ethics and animal welfare ethics.

\section{The 2012 Parliamentary Election Program}

\subsection{Ecology and animal welfare as two related concerns}

A critical inspection of the party's program for the 2012 parliamentary elections seems to indicate that, sometimes, the Animal Party tries to unify the concerns for individual animals and ecology. The party seems to perceive these themes as two major, interrelated concerns which are non-conflicting, both being threatened by human activities. For example, the election program notes that the way in which mankind uses animals can be considered as the biggest threat to the earth's ecology, and that $30 \%$ of biodiversity loss is due to livestock farming (Partij voor de Dieren 2012a). The program also points to the harmful effects of the fishing industry on marine ecosystems and the fact that most fish species are endangered due to overfishing (Partij voor de Dieren 2012a). For both fisheries and livestock farming, the program also points to the severe suffering and abuse of animals (Partij voor de Dieren 2012a). In the case of fish, it is said that they are also sensitive beings and hence should be protected against stress and pain prior to being slaughtered (Partij voor de Dieren 2012a). In the context of genetic modification, the election program says the following: "Genetic modification impairs the integrity of plants and animals. This technique also poses a high risk for people, animals and biodiversity" (Partij voor de Dieren 2012a, p. 10), and moments later it says: "Genetically modifying and cloning animals is ethically unacceptable and entails serious animal suffering" (Partij voor de Dieren 2012a, p. 10). Just like the examples of fisheries and cattle breeding, this latter human activity (i.e. genetic modification) is considered harmful for both animal welfare and the more abstract biodiversity. In the election program, it often happens that animal suffering and biodiversity loss, or, for example, animals and nature, are mentioned in the same phrase in the program's enumeration of what is being 
fought against/for (see: Partij voor de Dieren 2012a, pp. 6, 28, 33, 36). An additional, appealing example of this is the following proposition in the party program: "There will be a Ministry of Sustainable Development, Space, Energy and Animal Welfare, where the issues of environment, nature, water and animal welfare are bundled" (Partij voor de Dieren 2012a, p. 31). From the election program, it can thus be concluded that the Animal Party frames practically all issues relating to biodiversity or ecology in such a way that standing up for the individual animals clearly seems to be enhancing ecological values or biodiversity.

\subsection{The problematic relationship between ecological and animal welfare concerns}

From the previous section it is clear that the Animal Party tries to avoid the potential friction between animal ethics and eco-ethics. At the same time, for some issues covered in its election program, the Animal Party cannot prevent these topics from converging unintentionally and in a rather awkward way. For example, the election program says: "All plants and animals will be protected, even if they are not mentioned in European conventions. The same applies to natural values like wideness and quietness" (Partij voor de Dieren, 2012a, p. 14). Notably, this latter measure is listed under the heading 'Protecting nature'. This view seems to correspond with animal welfare ethics rather than with ecological ethics, since it is common ecological knowledge that preserving some vulnerable or threatened species may be hampered when another (more common) species is protected as well. At the same time, the election program also points to the fact that current conventions on e.g. biodiversity are hardly complied with and that the Animal Party is in favour of firm, enforceable agreements (Partij voor de Dieren 2012a). Because of this, the question arises as to whether some of the Animal Party's points of view might actually impede compliance with these same agreements.

Regarding zoos and petting farms, the election program says the following: "Zoos and petting farms do not show animals in their natural environment, but rather in cages or in small areas. Apathetic and stereotypical behaviour is therefore no exception in zoos. This way, one does not really contribute to increasing knowledge and appreciation of animals. On the contrary, visitors especially see animals in an unnatural context and 'learn' that it is apparently normal to keep animals under these circumstances" (Partij voor de Dieren 2012a, p. 24). The Animal Party even pleads for a different function for zoos: 'Zoos are transformed into (temporary) accommodation for animals that cannot maintain themselves in their original habitat or cannot be replaced therein' (Partij voor de Dieren 2012a, p. 24). These statements seem to imply that zoos' conservation function (important for eco-ethicists) is not supported by the Animal Party, whereas the shelter function is supported. This indicates that animal welfare is placed higher in the hierarchical order than such things as biodiversity and ecosystem preservation.

The friction between ecological and animal welfare concerns becomes particularly visible from the Animal Party's responses to specific issues that 
correspond to any of the problematic topics of 'hunting', 'exotic species', 'wild animals in trouble', 'introduced (semi-)wild animals' and 'natural behaviour of domesticated animals'. Each of these five issue categories, discussed below, include the party's vision, its position on more specific issues within the issue category (in the election program) and, finally, the response of the party on certain topics within the issue category that occur in reality.

\section{Five Issue Categories}

\subsection{Hunting - Vision}

The Animal Party's position on hunting is expressed as follows: "The Animal Party wants the intrinsic value and protection of the animals living in the wild to become the starting points for policy. In nature, there is no place for hunting" (Partij voor de Dieren 2012a, p. 14). It seems that the main reason for the Animal Party to oppose hunting is the priority that should be given to the intrinsic value of wild animals, whereby the party explicitly refers to 'the animals living in the wild'. Notably, the crucial link between hunting and its purpose of restoring an ecological balance (i.e. at least for some species) is not mentioned. In this way, the Animal Party claims to stand for the intrinsic value of wild animals, whereas simultaneously the 'interests' of other, indirectly affected wild animals (i.e. prey species of e.g. the fox) are not taken into account. Given that the interests of the wild animal that becomes 'identifiable' as a possible object of hunting seem to be placed above the interests of indirectly affected species and their ecological role, this statement expresses an animal welfare ethical point of view, rather than an eco-ethical one.

This is further supported by the following quote from the program that shows a slightly more nuanced vision on the part of the party: "Animals living in the wild will not be killed. Only when there are urgent reasons, for example when the animal is suffering or public health is threatened, can an exception be made" (Partij voor de Dieren 2012a, p. 14). Once again, the question is raised as to what the party thinks of the interests of vulnerable animals that are indirectly affected by perceived damage-causing animals. These former species often constitute crucial parts of ecological food webs and hence are essential for overall biodiversity. Apparently, biodiversity preservation is not regarded as urgent enough by the Animal Party to legitimize hunting.

\subsection{Hunting in practice (election program)}

Also interesting is the following illustrative quote from the party program: 'In the Netherlands, wild animals are being hunted for fun, often in the name of population management. This happens despite the fact that a large majority of the population thinks that hunting as a hobby should be prohibited.

Annually, two million wild animals are shot dead and another two million animals are shot (i.e. wounded). Young animals remain motherless, partner links are cruelly disrupted and group hierarchies and population dynamics are literally shot to pieces. Hunting contributes to overpopulation, 
since the removal of large numbers of animals stimulates reproduction. Culling, releasing and additionally feeding animals disturb the natural equilibrium' (Partij voor de Dieren 2012a, p. 25). In this context, the Animal Party also says that it wants to abolish the existing fauna management units (Faunabeheereenheden) (Partij voor de Dieren 2012a). This time, contrary to the former quotes on hunting, the Animal Party does relate hunting to population management. Nevertheless, the benefit of population management is seriously called into question by the party. It is even equated with pleasure hunting. Interestingly, the ecological rationale for hunting is refuted by means of ecological counterarguments (e.g. culling as disturbing the natural equilibrium). By questioning the ecological effects of hunting with ecological arguments, it seems that the Animal Party has at least some ecological consciousness. At the same time, it is striking that the logic of this ecological argumentation is completely contrary to conventional eco-ethical thinking, in which regularly hunting is regarded as necessary for maintaining the natural equilibrium of a disturbed ecosystem.

Another interesting statement by the party is as follows: "So-called harmful animal species, like geese, foxes and muskrats, are intensively suppressed in our country, often with no other result than the death of numerous animals. Geese, for instance, are gassed on a large scale, and annually more than 300,000 muskrats die a horrible death in a clamp or a drowning trap. No effect on safety has ever been proved. Also, tens of millions are annually spent on the pointless and crude suppression of animals living in the wild money that could be better spent on effective prevention" (Partij voor de Dieren 2012a, p. 14). Considering the questionable ecologically inspired anti-hunting stance of the Animal Party, the party's use of words like 'crude', 'horrible', 'intrinsic value' and 'protection' (i.e. of individual animals) in its argument (see the various quotes on hunting) seems to express an animal welfare point of view.

\subsection{Hunting in practice (in reality)}

Regarding the intended shooting of fallow deer in the Amsterdam water supply dunes (Amsterdamse Waterleidingduinen), the Amsterdam faction of the Animal Party strongly opposed this idea of the local government. The Animal Party Amsterdam explains this as follows: "The Animal Party Amsterdam thinks that shooting in this situation is unnecessary and observes that deer do not pose a threat to traffic, agriculture and nature. Moreover, in the past few years, there has not been a food shortage" (Partij voor de Dieren Gemeenteraadsfractie Amsterdam 2013, par. 1). Although it seems that the party is making an assessment based on this particular situation, moments later the same source notes: "The Animal Party pursues natural populations and processes. Nature manages itself. However, when nature is managed by humans, hunters artificially increase the mortality among healthy animals. This leads to the fact that a natural balance between the population and its environment cannot occur" (Partij voor de Dieren Gemeenteraadsfractie Amsterdam 2013). Hence, the Animal Party clearly suggests here - using an 
ecological rationale (irrespective of whether this is sound or not) - that it actually opposes all hunting, regardless of the situation. Moreover, the ecological argumentation here is contrary, once again, to more conventional ecological thought, in which such factors as the absence of top predators and areas that are small and fragmented are reasons why 'doing nothing' leads to imbalanced situations. In line with this, the 'human as hunter' could be required in order to keep such disrupted ecosystems in a balanced state. However, by rejecting the need for population control for the sake of protecting ecological functions, the Animal Party can safely claim to stand up for both individual animal welfare and broader ecological interests.

\section{Exotic Species}

\subsection{Vision}

The party's vision on exotic animals becomes clear from the following question that Mrs Marianne Thieme from the Animal Party asks in a Lower House debate about the shooting of the Indian house crow (which is referred to as an official invasive exotic, see: Partij voor de Dieren 2014a): "Do you share the opinion that the distinction between 'one's own, endemic animals' and 'immigrant, alien animals' is not of this age anymore? If not, why not?" (Partij voor de Dieren 2014a , par. 7).

The same topic was discussed by the Animal Party in the Zuid-Holland Provincial Executive. First of all, an Animal Party spokesperson explains that the house crow does not cause any nuisance or damage and is (contrary to what the province says) not an exotic species (Partij voor de Dieren Statenfractie Zuid-Holland 2012). However, the spokesperson adds a little later: "Besides, the Animal Party thinks that exotics must not be killed either, except when there is a serious danger to public health" (Partij voor de Dieren Statenfractie ZuidHolland 2012, par. 3). The animal welfare ethical point of view is manifest here and clearly placed above the broader ecological interests, which are simply not mentioned. Again, the question arises: what about the intrinsic value of the 'anonymous' but potentially harmed wild animals that are fundamental for the functioning of the ecosystem?

\subsection{Exotics in practice (election program)}

The party's election program pays explicit attention to the muskrat control by saying that fighting this species should be stopped and that the money saved should be spent on increased dyke surveillance and prevention measures (Partij voor de Dieren 2012a, p. 15).

The election program also notes the following, with respect to the preferred management of feral cats: "Feral cats (Felis catus) are no longer killed, but are caught, castrated or sterilized and brought back to the spot where they were caught. This way, we prevent the feral cat populations from expanding" (Partij voor de Dieren 2012a, p. 25). 
As both examples show, the Animal Party sees merit only in (prevention) measures which do not harm the damaging animals. Although prevention of population growth of a species (e.g. the feral cat) may be a solution in some cases, in others it may not. In any case, by opposing in principle the suppression of exotics, the party precludes the option of immediate control measures that could be necessary in some cases in order to prevent ecological damage.

\subsection{Exotics in practice (in reality)}

In the debate about the Indian house crow (as mentioned under 'Vision', this section), the answer to Marianne Thieme's question (see: 'Do you... why not?') from the Minister for Safety and Justice and the State Secretary for Economic Affairs clearly points to the dilemma that the Animal Party may cause for itself. The answer was as follows: "I suppose that you allude to the distinction made between protected animal species and invasive exotics. This distinction has been made in the Bird Directive and as such has been implemented in the Flora and Fauna Law. This precisely for the protection of the endemic animal and plant species" (Partij voor de Dieren 2014a, art. 6). Although earlier it became clear that the Animal Party wants to improve commitment to conventions on e.g. biodiversity, this debate fragment suggests that the Animal Party does not recognize the perceived need to distinguish between protected species and invasive, exotic species, whereby it opposes an essential assumption made in some of these conventions. Moreover, the interests of the wild animal are at stake here. By denying the difference in moral status between protected animals and exotic, invading animals, the Animal Party practically outlaws vulnerable species and their often unique role in the ecosystem. If it were up to the Animal Party, the right of the wild animal to remain untouched by humaninduced change agents (such as exotic species) is taken away from the animal. Consequently, it is difficult to see how the Animal Party can claim to cherish such things as ecosystems and biodiversity, if it is in principle against protecting the anonymous, but often ecologically significant, wild animal against identifiable 'intruders'.

Taking these examples together, it seems evident that the Animal Party takes an animal welfare ethical stance on the issue of exotic species. The party does not really know how to protect the indirectly affected animals (and hence the wider ecological functions and biodiversity) from the exotic colonists. Because of this, closing its eyes to the negative relation that may exist between exotics and ecological functioning appears to be the strategy that the Animal Party adopts here.

\section{Wild Animals in Trouble}

\subsection{Vision}

The Animal Party's vision regarding wild animals in trouble becomes apparent from the following quote from the 2012 election program: "In urban as well as 
in rural areas, animals living in the wild can get injured - often by humans. The Party for the Animals wants government to take responsibility for emergency aid to these animals" (Partij voor de Dieren 2012a, p. 15).

The fact that the Animal Party wants to take injured, wild animals out of their habitat to care for them is, in principle, a view in line with animal welfare thinking. An important point here is where to draw the line between helping and not helping. This becomes a bit clearer in the following statement expressed in the context of a recent national discussion in the Netherlands regarding a beached whale called Johannes. The party said the following: "The Animal Party thinks that, from the perspective of nature protection, intervention in nature should be as little as possible. However, when an animal living in the wild gets into serious distress under circumstances where human intervention can bring rescue or relief, the Animal Party advocates intervening from the legal duty of care and from the perspective of compassion" (Partij voor de Dieren 2012b, par. 2).

\subsection{Wild animals in trouble - in practice (election program)}

The Animal Party clearly shows that it wants to take care of individual wild animals. For pigeons and gulls, it would like to provide alternative nesting opportunities (Partij voor de Dieren 2012a). In the context of the wish to strengthen emergency aid to wild animals in both urban and rural areas (see 'Vision', this section), the party wants to reinforce and financially assist shelters for wild animals (Partij voor de Dieren 2012a). By arguing in favour of these kinds of measures, the Animal Party explicitly opts for the individual animal, since it does not reflect on the ecological effects of this human intervention. In order to appear as an ecology-minded party, the Animal Party should at least reflect upon this theme. The same view is also supported by the fact that the Animal Party wants to prohibit dolphinariums from being a zoo, and only sees a function for them as temporary shelter for marine mammals that have been beached (Partij voor de Dieren 2012a).

\subsection{Wild animals in trouble - in practice (reality)}

The latter example of marine animals can be linked to the example of Johannes, the beached whale. The issue does not leave the Animal Party untouched, as appears from the following message on Twitter by Marianne Thieme: "The humpback whale weeps and seems to give up hope" (Twitter message by Marianne Thieme in Anonymous 2012).

The Animal Party was quite active in this discussion and also said the following: "The humpback whale that was beached on the sand island of Razende Bol on Wednesday could not possibly return to the sea under its own steam, and for that reason rescue was necessary" (Partij voor de Dieren 2012b, par. 2). Although the beaching of a whale is quite exceptional and the desire to help such an extraordinary animal that is clearly out of place is quite understandable, the question remains as to where to draw the line between intervening and not intervening. In the context of the same issue, the Animal Party also aims for an official government protocol about how to deal with 
beached mammals, and it is a proponent of leaving the animal carcasses as a food source in nature (Partij voor de Dieren 2012b), thereby showing ecological awareness.

\section{Introduced Semi-Wild Animals}

\subsection{Vision}

Regarding the release of animals into the wild, the Animal Party is again very clear when it says: "It is well known that the Animal Party is against the release of wild animals" (Partij voor de Dieren 2010a, par. 20). This view appears for example when the Animal Party asks very critical questions in some Lower House debates on experiments with released wisents (European bison) and otters (see e.g.: Partij voor de Dieren 2007; Partij voor de Dieren 2014c).

In the context of the Oostvaardersplassen area (a Dutch area in which herds of several ungulate species were introduced after the area had been allowed to develop into a new nature area) (Author, 2014), the Animal Party's vision on introduced semi-wild animals also becomes apparent: "The Animal Party is against the release of animals and would therefore never have supported the original design of the Oostvaardersplassen" (Partij voor de Dieren 2014d). This view is largely at odds with an ecological point of view, in the sense that the restoration of ecological processes may sometimes require the introduction of a certain keystone species that can push an ecosystem in the right direction. Given that introductions tend to have an experimental character, with sometimes unknown effects on the introduced animals, it would be understandable if the Animal Party opposed this practice from the point of view of individual animal welfare.

\subsection{Introduced semi-wild animals in practice (election program)}

The issue of introduced animals is not well represented in the election program. It plays a role only when the program says something in the context of the Oostvaardersplassen. Currently, the idea is that nature in the area can take its own course. The party program says the following about it: "The animals in the Oostvaardersplassen get more shelter and access to the surrounding forests, as is recommended by the Gabor commission, in order to prevent unnecessary suffering. The connection with the Veluwe (Oostvaarderswold) is quickly realized" (Partij voor de Dieren 2012a, p. 14). Given that the construction of connections with other areas may be beneficial from an animal welfare as well as from an ecological point of view, it is striking that only the advantage for animal welfare is explicitly mentioned.

\subsection{Introduced semi-wild animals in practice (reality)}

Outside its election program, the Animal Party says the following in regard to the Oostvaadersplassen: "The situation in the Oostvaardersplassen is not as simple as it seems, and the measures that seem the most obvious are certainly not the most animal-friendly ones. Parties like CDA, VVD and PVV ignore the 
consequences that measures like additional feeding and active shooting (management hunting) have for the animals. Both measures will lead to the shooting of increasing numbers of healthy animals. Moreover, it is striking that precisely these parties stopped the expansion of the Oostvaardersplassen with the 'Hollandsche Hout', a forested area in which the animals could find more shelter" (Partij voor de Dieren 2010b, par. 6). In this case also, the Animal Party reasons mainly from an animal welfare point of view, by repeatedly referring to animals as individuals, whereas the broader entities in which wild animals are contained, like populations and species, are not mentioned. Also, the ecologically beneficial measure of enlarging the animals' available habitat is perceived solely from an animal welfare point of view.

The Animal Party is against introducing animals in general: "The Animal Party is against the release of animals and would therefore never have supported the original design of the Oostvaardersplassen. Given, though, that the red deer, Heck cattle and Konik horses are living there in the wild, it is important that the animals are left alone as much as possible, and that the herds can perform their natural behaviour, with as little human intervention as possible. At the same time, man does have the duty to prevent unnecessary suffering. This requires a carefully balanced judgement regarding what is good for the individual animals and for the herds as a whole" (Partij voor de Dieren 2014d). Although eco-ethicists detest nature's contamination with exotic and domestic species (Callicott 1989), they can be in favour of particular kinds of (re-)introductions, such as in the Oostvaardersplassen in which the introduced ungulates are intended as ecological replacements of indigenous, but extinct, species (see: Vera 2009). Therefore, the Animal Party's principled rejection of all animal releases is contrary to eco-centric thought. At the same time, the Animal Party also refers to specific species and to the natural behaviour of herds. However, it takes another turn when it refers, once again, to the duty of humans to prevent unnecessary suffering of animals.

In the last sentence of the last quote, the party admits that there is a dilemma between optimizing individual animal welfare and the needs of broader entities (i.e. the herd in this case). Although the Animal Party definitely acknowledges the importance of leaving the herds alone, it also says: 'The Animal Party thinks that the welfare of the individual animal should be given priority, without impairing the freedom and the natural behaviour of the herd, and with as little human intervention as possible' (Partij voor de Dieren 2014d). The party is clearly torn between two ideas as it continuously jumps from animal welfare ethical thinking to eco-ethical thinking. In the end, the party does not come up with an integrative view that could function as guidance for the party in any given case. Even more so, the above quotes seem to suggest that the final judgement of the party will always be in favour of the individual animal. In this way, the natural domain, comprised of the self-regulating ecosystem (on the convenient assumption that 'self-regulating' is applicable here), cannot be said to be safe against potentially disturbing (to speak in ecoethical terms) human intervention. 


\section{Natural Behavior of Domesticated Animals}

\subsection{Vision}

About keeping domesticated animals, the Animal Party says the following: "Dutch people live with animals. In nearly half of households, a cat or dog is part of the family. However, that's not all. Kangaroos, caimans and barn owls are also sold as pets. In total, there are currently about 28 million pets in our country. These are living creatures; no gadget, toy or accessory. Therefore, pets deserve protection. That starts with respecting the intrinsic value and the nature and needs of the animal" (Partij voor de Dieren 2012a, p. 20). Given that this topic is confined to domesticated animals, wild animals in captivity are outside the scope of this topic. Whereas the Animal Party is rather active in trying to prohibit owning and using wild animals for all kinds of purposes (see e.g. Partij voor de Dieren 2012a), it does not really have an overall vision on the extent to which domesticated animals, in particular, should be allowed to show natural behaviour.

\subsection{Natural behavior of domesticated animals in practice (election program)}

To show that the Animal Party is especially concerned about the ability of wild animals in captivity to exert natural behaviour, the following fragments from the party program are relevant. First of all, the party says the following: "In the Netherlands, it is allowed to keep nearly any animal species that you can imagine. Tropical birds, the raccoon dog, the bullfrog, the ostrich or iguanas; the list is endless. Although everyone understands that many animals by their nature and needs are not suitable to be kept as pets, government still does not intervene" (Partij voor de Dieren 2012a, p. 20). In the same context, the party program says: "As soon as possible there will be a (short) positive list: animals that are on the list may be kept as pets, animals that are not on the list may not be bred and traded as pets anymore. (...) When determining the positive list, the natural behaviour, the nature and needs of the animal are put center stage" (Partij voor de Dieren 2012a, p. 20).

These statements show that the Animal Party wants wild animals to be in nature instead of in people's hands. Given that it uses words like the 'nature and needs' and the ability to exercise 'natural behaviour', it seems that the integrity of the individual animal rather than ecological integrity is the deciding factor for its position on this issue.

However, in a few cases, the Animal Party says something on this issue that specifically addresses domesticated animals. In the context of domesticated animals in agriculture, the Animal Party says the following: "The animals which are kept in agriculture must be accommodated and cared for in accordance with their nature and behaviour. The systems must be adapted to the needs of the animals instead of the other way around" (Partij voor de Dieren 2012a, p. 7). As an example of this, it adds: "All animals get free range to the outside and have sufficient shelter possibilities there. In that case, chickens can have a dust bath, pigs can root and cows and goats can graze in the meadow" (Partij voor de 
Dieren 2012a, p. 7). The point here is that animals in conventional agriculture and horses are domesticated animals and, in addition, that petting farms are often places which possess mostly domesticated animals. Hence, these statements suggest that the Animal Party also wants domesticated animals to exercise their natural behaviour, even though these animals belong fully to the cultural domain of man. In this way, one can see the tendency to sometimes pull the natural domain into the cultural sphere. The Animal Party's position on this issue is clearly in accordance with an animal welfare point of view, given that for them the welfare of the individual animal is the key concern in these examples.

\section{Conclusion}

As becomes apparent from the name and also from the Animal Party's 2012 election program, the party wants to stand up for domesticated animals as well as wild animals. At the same time, more abstract things like ecological values and biodiversity are among its major concerns as well. In line with eco-ethics, in which protecting the integrity of broader entities like populations, species and ecosystems is central, preserving this integrity means leaving the wild animal alone, even when it is suffering or dying. From an eco-ethics view, applying an animal welfare ethics to wild animals is in conflict with these wider entities of which these wild animals are components. The question addressed in this paper was, therefore, how a political party, and in particular the Animal Party, can at the same time claim to stand up for the interests of animals as individuals as well as for the particular interests of wild animals (i.e. as anonymous components of broader entities).

The election program and the real-life issues that we analysed did indeed reveal the friction that was expected. This often happened in those cases in which there was a category of identifiable animals that were 'suffering' or about to suffer, while, at the same time, other non-identifiable animals had the potential to be negatively affected by this former group (see e.g. the party's resistance to hunting harmful species). In cases in which the Animal Party pleaded in favour of helping individual wild animals that were suffering (see e.g. the Oostvaardersplassen case and the beached whale), the negative effect on the ecosystem was more intangible. Rather, the eco-ethical integrity principle of ecosystems and their components (i.e. the wild animals) were at stake here. The issue of distinguishing between protected versus common or even exotic species emerged when, in the party's election program, the wish to make nature conventions more firm and enforceable was contrasted by the explicit wish to also protect all the plants and animals that are not mentioned in these nature conventions.

The Dutch Lower House debate on the Indian house crow, in which the Animal Party refused to differentiate between the status of protected wild species as opposed to invasive exotics (see also the related examples on raccoon dogs, muskrats and feral cats), implies that the right of the wild animal to keep its integrity by continuing to fulfil its role in the wider ecosystem is 
taken away. In this way, it is hard to see how the Animal Party can vindicate its claim to fight for biodiversity and ecosystems. It may therefore not be a surprise that it is fundamentally against management hunting in general (i.e. not specifically exotics) as well. It is therefore noteworthy that in some cases it alludes to ecological arguments when pleading against hunting in certain cases. In this way, it gives the impression that the ecological arguments are just an instrument in case the moral ones do not find support. This is supported by the fact that its ecological arguments are often diametrically opposed to common eco-ethical thinking.

On the issue of caring for wild animals also, the Animal Party seems to have rather animal-centric views. An illustrative example here is its wish to strengthen the emergency aid for animals living in the wild. Another is the fact that it does not support zoos' conservation function, and instead, wants them to be temporary shelters for individual wild animals in need. The fact that zoos' conservation function is not supported by the Animal Party is a problematic position from an ecological perspective, since some endangered species fulfil a crucial role in their ecosystem and hence should be bred in captivity and subsequently released into the wild. This would contribute to preserving the survival of the species and hence the intactness of the ecosystem as a whole. At the same time, zoos' shelter function is supported by the Animal Party. This is once more an indication that animal welfare is prioritized over ecological values and biodiversity.

Regarding the issue of the introduction of (semi-)wild animals, it can be said that the Animal Party is simply against this. This conflicts with the ecoethical arguments in favour of the managed introductions of some ecologically important species. For the Oostvaardersplassen, the Animal Party does point to the fact that the animals are part of a herd and are living in the wild and that therefore intervention should be minimized. Nevertheless, it repeatedly jumps from an animal welfare focus on individual animals to the need to leave wild animals alone. This is a further testimony to our view that it will, in the end, always prioritize the wellbeing of the individual animal.

In sum, everything seems to indicate that the Animal Party does feel responsible for the domestic as well as the wild animal, but that it has, compared to eco-ethics, a different conception of what wild animals are. Rather than perceiving wild animals as mere components of wider entities (i.e. according to eco-ethical thinking), the Animal Party starts to personalize wild animals at the moment that their wellbeing can be detected and actively improved. In some cases, this position can be very detrimental for the 'anonymous' assemblage of animals, which can be negatively affected by, for instance, invasive exotics. It is evident that, in this kind of issue, the Animal Party is simply not able to stand up for all animals, since a small group of (potentially) harmful animals is given priority over an interrelated chain of numerous other (affected) animals. In other cases, it could be said that the constitutive role of wild animals in wider entities such as populations, species and ecosystems is impaired when there is intervention in the lives of animals 
(e.g. when aid is provided). In this case, the integrity of the wild animal may be perceived as being impaired by unnecessary intervention in the ecosystem. Taking all of this together, it becomes clear that the Animal Party cannot really claim to be a party for all animals. Too often, an animal welfare ethics is applied to wild animals that should be treated - given that the Animal Party aims at preserving ecological values too - according to eco-ethical principles.

Since we have the impression that some of the ecological promises in the party's election program cannot be fulfilled, reconsideration and clarification of some of the party's main principles could probably reduce some undesirable ambiguity. One possible way of removing the incongruence between the Animal Party's words and deeds may be to differentiate the term 'animals' into different categories. These categories could then call for the application of either animal welfare ethical or eco-ethical principles. Categories that one could think of are, for instance, 'pets', 'circus animals', 'zoo animals', 'semi-wild animals' and 'wild animals'. A drawback of this framework might be that, because of the promoted black-and-white thinking that is inherent in this framework, the chosen position for some categories might be overly animalwelfare ethical or overly eco-ethical. Such a rational approach to animal-related issues might harm the reputation of the Animal Party as an animal-friendly and idealistic party.

A second alternative approach would be to construct an integral and comprehensive vision in its election program, designed in such a way that it offers guidance in any possible situation and scenario. Logically, this would probably come down to the fact that, in principle, animal welfare is always regarded as the sole main priority. This would probably also apply to the cases in which semi-wild animals are involved. An exception could, for instance, be made for 'purely' wild animals which, at a given moment, do not 'qualify' for human intervention. In this way, the party would be able to consistently convey its main principles and would not have to come up with questionable ecological rationales when ecological values are at stake. It would be able to simply choose the wellbeing of the identifiable, and hence tangible, individual animal.

Although both these proposed approaches may have their disadvantages, they would undoubtedly mean a significant improvement in the current situation, in which the Animal Party is frequently torn between two often irreconcilable ideas, resulting in rather awkward and ambiguous positions in which questionable ecological arguments are used. Only when the Animal Party comes up with an approach that does justice to the complexity of everyday reality will it be able to live up to its ideals and promises.

\section{References}

Anonymous. 2012. "Bultrug Johannes niet meer te redden." Volkskrant.nl. URL: http://www.volkskrant.nl/vk/nl/2664/Nieuws/article/detail/3362778/ 2012/12/14/Bultrug-Johannes-niet-meer-te-redden.dhtml (retrieved on 01.07.2014). 
Callicott, J. B. 1989. In Defense of the Land Ethic: Essays in Environmental Philosophy. Albany, NY: State University of New York Press.

Gamborg, C., B. Gremmen, S.B. Christiansen, \& P. Sandoe. 2010. "DeDomestication: Ethics at the Intersection of Landscape Restoration and Animal Welfare." Environmental Values, Vol. 19: 57-78.

Janssen, C. \& M. Drenthen. 2013. "Wij willen aaibaarheid”. Volkskrant.nl March 18th.

URL: http://www.volkskrant.nl/vk/nl/2844/Archief/archief/article/detail/34 10185/2013/03/16/Wij-willen-aaibaarheid.dhtml (retrieved on 01.07.2014).

Klaver, I., J. Keulartz, H. Van den Belt, \& B. Gremmen. 2002. “Born To Be Wild: A Pluralistic Ethics Concerning Introduced Large Herbivores in the Netherlands." Environmental Ethics, Vol. 24: 3-21.

Partij voor de Dieren. 2007. "Kamervragen aan minister van LNV over proef Staatsbosbeheer met 6 wisenten." partijvoordedieren.nl. URL: https://www.partijvoordedieren.nl/tweedekamer/kamervragen/i/18 (retrieved on 01.07.2014).

Partij voor de Dieren. 2010a. "Bijdrage Ouwehand Spoeddebat Oostvaardersplassen.” partijvoordedieren.nl. URL: https://www.partijvoordedieren.nl/tweedekamer/speeches/i/528 (retrieved on 01.07.2014).

Partij voor de Dieren. 2010b. "Werkbezoek Oostvaardersplassen." partijvoordedieren.nl. URL: https://www.partijvoordedieren.nl/recent/news/i/3064 (retrieved on 01.07.2014).

Partij voor de Dieren. 2011. "2. Geschiedenis." partijvoordedieren.nl URL: https://www.partijvoordedieren.nl/downloads/www/2011/08/131315 4600_2._De_Geschiedenis_van_de_PvdD_2011.pdf (retrieved on 01.07.2014).

Partij voor de Dieren. 2012a. "Hou vast aan je idealen - laat ze niet wegcijferen', Verkiezingsprogramma Partij voor de Dieren - Tweede Kamerverkiezingen 2012." partijvoordedieren.nl. URL: https://www.partijvoordedieren.nl/downloads/verkiezingsprogramma2 012.pdf (retrieved on 01.07.2014).

Partij voor de Dieren. 2012b. "Bultrug Johannes overleden." partijvoordedieren.nl. URL: https://www.partijvoordedieren.nl/recent/news/i/6967/bultrugjohannes-overleden (retrieved on 01.07.2014).

Partij voor de Dieren. 2014a. "Vragen over het afschieten van huiskraaien." partijvoordedieren.nl. URL: https://www.partijvoordedieren.nl/tweedekamer/kamervragen/i/3199 (retrieved on 01.07.2014).

Partij voor de Dieren. 2014b. "Motie Thieme: verbod afschot wasbeerhonden." partijvoordedieren.nl. URL: https://www.partijvoordedieren.nl/tweedekamer/moties/i/2490 (retrieved on 01.07.2014). 
Partij voor de Dieren. 2014c. "Vragen over het lot van uitgezette otters in Nederland." partijvoordedieren.nl. URL: https://www.partijvoordedieren.nl/tweedekamer/kamervragen/i/316.1 (retrieved on 01.07.2014).

Partij voor de Dieren. 2014d. "Oostvaardersplassen." partijvoordedieren.nl. URL: https://www.partijvoordedieren.nl/standpunten/i/527/oostvaardersplas sen (retrieved on 01.07.2014).

Partij voor de Dieren, Gemeenteraadsfractie Amsterdam. 2013. "Afschieten damherten onnodig." amsterdam.partijvoordedieren.nl. URL: https://amsterdam.partijvoordedieren.nl/recent/news/i/7631/afschiete n-damherten-onnodig (retrieved on 01.07.2014).

Partij voor de Dieren. Statenfractie Zuid-Holland. 2012. "Partij voor de Dieren tegen uitroeiing huiskraai Hoek van Holland." zuidholland.partijvoordedieren.nl. URL: https://zuidholland.partijvoordedieren.nl/recent/news/i/6981 (retrieved on: 01.07.2014).

Swart, J.A.A. 2005. "Care for the Wild: An Integrative View on Wild and Domesticated Animals." Environmental Values, Vol. 14: 251-263.

Vera, F.W.M. 2009. "Large-scale nature development - the Oostvaardersplassen." British Wildlife, Vol. June: 1-8.

Vereniging Het Edelhert. 2011. "Voorstel voor landelijk beleid ten aanzien van damherten." Hetedelhert.nl. "URL: http://www.hetedelhert.nl/images/stories/pdf/Beleidsvoorstel_Damher ten.pdf (retrieved on 15.03.2014). 


\title{
Ruud Otten \& Bart Gremmen
}

(Wageningen University, Rotten@aresco.nl, bart.gremmen@wur.nl )

\section{Political Parties and Environmental Ethics: The Case of the Dutch Party for the Animals}

\begin{abstract}
The Dutch Partij voor de Dieren (Party for the Animals), the only political party devoted to animals in the world, wants to take wild as well as domestic animals under its wing and, hence, to remove the traditional dividing line between both domains. How can the Animal Party at the same time claim to stand up for the interests of animals as individuals as well as for the particular interests of wild animals? Rather than perceiving wild animals as mere components of wider entities, the Animal Party starts to personalize wild animals at the moment that their wellbeing can be detected and actively improved.
\end{abstract}

Keywords: wild animals, domesticated animals, animal welfare ethics, ecoethics Ethics in Progress (ISSN 2084-9257). Vol. 7 (2016). No. 1, Art. \#8, pp. 118-135. doi: 10.14746/eip.2016.1.7 